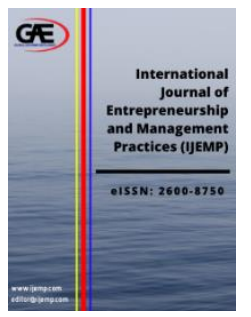

\author{
INTERNATIONAL JOURNAL OF \\ ENTREPRENEURSHIP AND \\ MANAGEMENT PRACTICES \\ (IJEMP) \\ www.ijemp.com
}

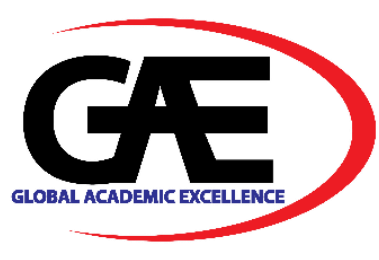

\title{
INVESTIGATING PWD REVISIT INTENTION FOR ENTREPRENUERIAL PASTRY COURSE AT SELAYANG COMMUNITY COLLEGE: THE MODERATOR ROLE OF GENDER
}

\author{
Mohd Hyrul Abu Karim ${ }^{1 *}$, Mohd Khaidir Che Hassan ${ }^{2}$, Azmarita Muhamad Bahari ${ }^{3}$ \\ 1 Department of Hotel Operation, Selayang Community College (KKSY), Malaysia. \\ Email: hyrul@kkselayang.edu.my \\ 2 Department of Culinary, Selayang Community College (KKSY), Malaysia. \\ Email: khaidir@kkselayang.edu.my \\ 3 Department of Culinary Selayang Community College (KKSY), Malaysia. \\ Email: azmarita@kkselayang.edu.my \\ Corresponding Author
}

\section{Article Info:}

Article history:

Received date: 30.12 .2020

Revised date: 05.01 .2021

Accepted date: 16.01.2021

Published date: 01.03.2021

To cite this document:

Karim, M. H. A., Che Hassan, M. K., \& Bahari, A. M. (2021). Investigating PWD Revisit Intention For Entrepreneurial Pastry Course At Selayang Community College: The Moderator Role Of Gender. International Journal of Entrepreneurship and Management Practices, 4 (13), 22-33.

DOI: $10.35631 /$ IJEMP.413002.

This work is licensed under CC BY 4.0

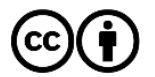

\begin{abstract}
:
People with disabilities (PWD) empowerment has become a topic of international discussion. Individuals from this population are more likely to be in low-paying jobs and have the lowest prospects for promotion of any group across most industries. It is important to train PWD students to be more confident and to become semi-skilled workers before they enter the workforce. In 2020, there is no course conducted at Selayang Community College (KKSY) for the PWDs in the Food and Beverage (F\&B) industry training because of the pandemic covid-19. This study, therefore, aimed to examine the relationships between the three independent variables (attitude, subjective norms, and perceived behavioural control) and the dependent variable (PWD students' revisit intention to attend pastry courses), using the Theory of Planned Behaviour (TPB) with gender as the moderating variable. The quantitative method was employed to investigate the relationships between the three independent variables in TPB and PWD's revisit intention. Questionnaires were used to obtain data from 146 PWD students in the Klang Valley area. This study found that all three independent variables significantly influenced PWD students' intention to attend pastry courses at KKSY. Perceived Behavioural Control or Individual belief and control is important to PWD students and also helps teachers to predict what types of short course they most likely will attend to expand their skill acquisition. This study contributes to the body of knowledge regarding the PWD students' attitude, subjective norms, and perceived behavioural control to the area of hospitality education research, Furthermore, educators should give more attention and encouragement to female PWD students to increase their entrepreneurial spirit.
\end{abstract}


Keywords:

PWD, Revisit Intention, Pastry Courses

\section{Introduction}

In 2012, United Nations Economic and Social Commission for the Asia Pacific convention came up with the slogan "Make the Right Real" for People with Disabilities (PWD) to be seen, heard and counted (ESCAP, 2012). The key principles and policy direction for the rights of PWD is to respect the inherent dignity, individual autonomy, and independence of persons with disabilities. Other principles also include non-discrimination, full and effective participation and inclusion into society, respect for differences and acceptance of PWD as people who are a part of human diversity and humanity. The convention also stressed the equality of opportunity, accessibility, and gender equality and also respect for the evolving capacities of PWD children to preserve their identities.

People with disabilities have become an issue of international focus with an aim to enhance their opportunities and chances to work like normal people in workforce. PWD today are facing the likelihood of high unemployment, low salary, and little chance of job promotion. They are also being segregated from the mainstream professional labour market. In Prasetya and Mawardi's (2018) report, the World Health Organization (WHO) organized and divided people into groups based on different health conditions such as physical, mental illness, cognitive deficits, sensory deficits, and intellectual or developmental issues. Different disabilities engender different approaches. McDonnall and Lund (2020) stated that negative employer attitudes have consistently been identified as a barrier to PWD employment. A negative employer attitude may be due to negative stereotypes about the abilities of PWD. For example, the employer might believe that they are not productive and capable of working with "normal" people in a work setting. Consequently, the government has introduced an employment support service programme called 'Job Coach' provided by several government departments and nongovernmental organizations (NGOs).

In Malaysia, Act 685 in the Person with Disabilities Act of 2008states that a PWD should not be excluded from the general education system, and that children with disabilities should not be excluded from preschool, primary, secondary and tertiary education. The aim of the law is to foster equality between individuals with and without disabilities. This amounts to providing vocational training and learning throughout life. Currently there are more than 700 special education integrated programs in Malaysian primary and secondary schools, including several in higher learning institutions. In order to provide training for PWD in higher education institutions, they special facilities have been created, along with special courses utilizing different techniques and methods. Well-trained teachers are hired to assist them in their learning to ensure that course learning is achieved and well implemented.

At Selayang Community College (KKSY), there are several courses offered for PWD to enhance their job skills before they enter the workforce. Although there is a lot of learning problems and difficulties to undergo a course, the technical educators do not see any barrier for them to gain skills and knowledge. A total of 122 courses were conducted between 2018 and 2019 at KKSY. Most of the PWD courses were for pastry courses, followed by culinary and 
automotive courses. However, there was no pastry courses conducted in 2020 due to the Covid19 pandemic. It has raised concern among KKSY educators about the students' intention to continue gaining technical and vocational skills. This study, therefore, examine PWD's revisit intention to attend pastry courses at KKSY using the Theory of Planned Behaviour (TPB) by Ajzen (1991).

\section{Literature Review}

\section{PWD and Technical and Vocational Education Training}

Technical vocational education and training is a form of education involving the general education, technologies and related sciences. It is also getting hold of practical skills, attitudes, understanding and knowledge relating to occupations in various sectors of economy and social life which lead to industrial development (Engr Amaechi, Orlu, Obed, \& Thomas, 2017). Malaysian government has five main focuses in national education, namely empowering students with special needs and instructions to improve the basic facilities of poor schools in addition to system reform, digital reform and Technical and Vocational Education Training (TVET). This step is in line with the vision themed 'Education for All' involving four core groups, namely the PWD who are also students with special needs, B40 group, students and teachers (Berita Harian, 21 December 2019).

The higher education institutions must offer vocational training and job grading, as well as career counselling, and PWD students must register for these (Dwivedi, 2018). Nasri, Hamzah and Udin (2010) mentioned that PWD educators must emphasize on the abilities, functionality, skills, development, mastery and achievement of children in developmental skills. Therefore, it is important to provide a curriculum appropriate to the skill level and the PWD's knowledge. This is in line with the goal of special education in Malaysia that is to provide continuity of quality programs to meet the needs and special abilities for children with special needs in the normal environment. In order to motivate PWD students, they should be treated equally as an ordinary person (Rosli, Mahmud \& Mahbob, 2016). Ahmad, Jalil and Rahman (2020), Tahir and Mustafa (2008) and Prasetya and Mawardi (2018) suggested that entrepreneurial education is an innovative approach to empower PWD, aimed to create self-confidence and independency in social and economy aspect of their daily live. It is hoped that PWD would have entrepreneurship spirit to be self-employed.

KKSY play their roles in lifelong learning by offering various short courses to cater the needs of PWD'S such as pastry courses, culinary courses, creative hands-on courses, as well as automotive courses. The vocational educators have given their best to provide PWD with suitable facilities and access of learning which lead to the recognition of the college as one of the leading higher learning institutions that has the needed access for PWD students in Malaysia. However, in 2020, the statistics show that none of the pastry courses had been conducted following the Covid-19 pandemic outbreak. Thus, the researchers attempt to learn the PWD's intention to continue attending the pastry courses at KKSY in the near future using TPB theory with gender as the moderating variable in question (Ajzen, 1991).

\section{Theory of Planned Behaviour (TPB)}

The Theory of Planned Behaviour has been widely applied to predict and understand changes of behaviour (Ajzen, 2020). In this study, TPB by Ajzen (1991) was chosen to measure the relationships among the five variables in the framework. In TPB, the scholar stated that the stronger the attitude towards behaviour, subjective norms and perceived behaviour control, the 
stronger the individual intention to perform the behaviour under consideration. In addition, gender was tested as the moderating variable in the framework. Several scholars such as Bakolo (2020), Sherwani, Ali, Ali, Hussain and Gul (2018), Shodipe and Ohanu (2020), Sun, Liang and Wong (2017) and Yarimoglu and Gunay (2019) have used TPB as the underpinning theory for their research in education.

\section{Attitude towards behaviour}

Ajzen (2020) stated that attitude towards the behaviour is assumed to be a function of readily accessible beliefs regarding the behaviours' likely consequences, termed behavioural beliefs. A behavioural belief is the person's subjective probability that performing behaviour of interest will lead to certain outcome or provide certain experience. Attitude is an index of the level to which an individual likes or dislikes the evaluation of the behaviour in question (Ajzen, 1991). Thus, in this study, PWD attitude can be defined as predisposition or feeling towards continuing to attend pastry courses in KKSY in the near future. The result can be favourable or unfavourable, good or bad, and like or dislike (Lam \& Hsu, 2006). Bokolo (2020), Ilman, Ananda and Pohan (2020) and Manosuthi, Lee and Han (2020) found that the attitude of individual is a strong predictor of their intention toward accepting the behaviour in question. In contrast, Raab, Baloglu and Chen (2017), as well as Joo, Seok and Nam (2020) found that the attitude is insignificant in their study. Due to the uncertainty of findings in previous literature, the researchers in this study proposed that:

H1: Attitude has a relationship with the revisit intention of the PWD to continue attending pastry courses at Kolej Komuniti Selayang.

\section{Subjective Norm}

Yeou (2016) described subjective norm as normative opinions about the other people's expectations that engender a social pressure to behave in a way that aligns with the perceived expectation. Subjective norm is the second predictor in TPB. It consists of individual normative belief and motivation to comply (Ajzen, 1991; Ajzen, 2020). Magdelene, Ramayah and Amin (2015) explained that subjective norm in TPB holds the person's motivation to engage in chosen behaviour will be determined by the significant referent groups' preferences. In the context of this study, subjective norm is defined as a set of values that exert social influences on PWD to continue attending pastry courses at KKSY. Ashraf, Hou, Kim, Ahmad and Ashraf (2020), Jing Wang et al., (2018), as well as Soorani and Ahmadvand (2019) found that subjective norm is a significant predictor to the individual's intention. On the other hand, in a recent study, Wang and Wong (2020) found that subjective norm is insignificant with behavioural intention. Thus it is worth for the researchers to find out the answer in this research context. Therefore, it is proposed that:

H2. Subjective norm has a relationship with the revisit intention of the PWD to continue attending pastry courses at Kolej Komuniti Selayang.

\section{Perceived Behaviour Control}

Perceived behavioural control (PBC) is assumed to be based on accessible control beliefs (Ajzen, 2020). These beliefs are concerned with the presence of factors that can facilitate or impede performance of the behaviour. Control factors include required skills and abilities; availability or lack of time, money, and other resources; cooperation by other people; and so forth. A control belief is defined as a person's subjective probability that a given facilitating or inhibiting factor will be present in the situation of interest (Ajzen, 1991). Hence, in this study, $\mathrm{PBC}$ is defined as the degree to which PWD believe that an individual has a control over his or her personal and external factors that may encourage or repress the behaviour. Previous Copyright (C) GLOBAL ACADEMIC EXCELLENCE (M) SDN BHD - All rights reserved 
studies evaluating $\mathrm{PBC}$ as predictor to influence intention in their studies also found a significant relationship between PBC and individual intention (Abdullah, Islam \& Neela, 2020; Raab et al., 2017; Soorani \& Ahmadvand, 2019). Conversely, Yarimoglu and Gooney (2019) found that PBC is insignificant with behavioural intention. Due to the wavering of the previous findings, the researchers posit that:

H3. Perceived behavioural control has a relationship with the revisit intention of the PWD to continue attending pastry courses at Kolej Komuniti Selayang.

\section{Revisit Intention}

Lee, Jeong and Qu (2019) stressed that revisit intention is one type of behavioural intention and it represents customers' intention to visit the location again in the future in order to experience the destination, goods, or brand. Revisit intention has been recognized as a significant behavioural loyalty (Baker \& Crompton, 2000). In TPB by Ajzen (1991), behavioural intention represents an individual's specific planned behaviour, and the likelihood of an action based on his or her expectations. Several studies have used revisit intention in TPB such as Hasan et al. (2020), Manosuthi, Lee \& Han (2020) and Suid et al., (2017). Based on the previous literature, researcher decided to make revisit intention as the dependent variable in the framework to answer the research objectives.

\section{Gender as moderator variable in TPB}

In this study, the researchers attempted to see the impact of personal variables on PWD revisit intention to continue attend pastry courses at KKSY. Personal variables are related to personal characteristics, demographic and previous experience (Ilman et al., 2020). The three most studied personal variables are gender, psychological and personal background. Several studies have shown that men have greater intention than women through more positive attitude (Strobl, Kronenberg, \& Peters, 2012). This study used gender as the moderating variable in the relationships between the three variables in the TPB (attitude, subjective norm, and perceived behaviour control) and the revisit intention, as operated in the previous literature (Bo Meng \& Han, 2018; Ilman et al., 2020). Thus, the following hypotheses are established:

H4a. Gender has a moderating effect on the relationship between attitude and PWD revisit intention to continue attending pastry courses at Kolej Komuniti Selayang.

$H 4 b$. Gender has a moderating effect on the relationship between $S N$ and $P W D$ revisit intention to continue attending pastry courses at Kolej Komuniti Selayang.

H4c. Gender has a moderating effect on the relationship between PBC and PWD revisit intention to continue attending pastry courses at Kolej Komuniti Selayang.

Based on the above literature, it is relevant for the researchers to adapt and examine the three independent variables in the TPB with the revisit intention of the PWD to continue attending pastry courses at KKSY. 


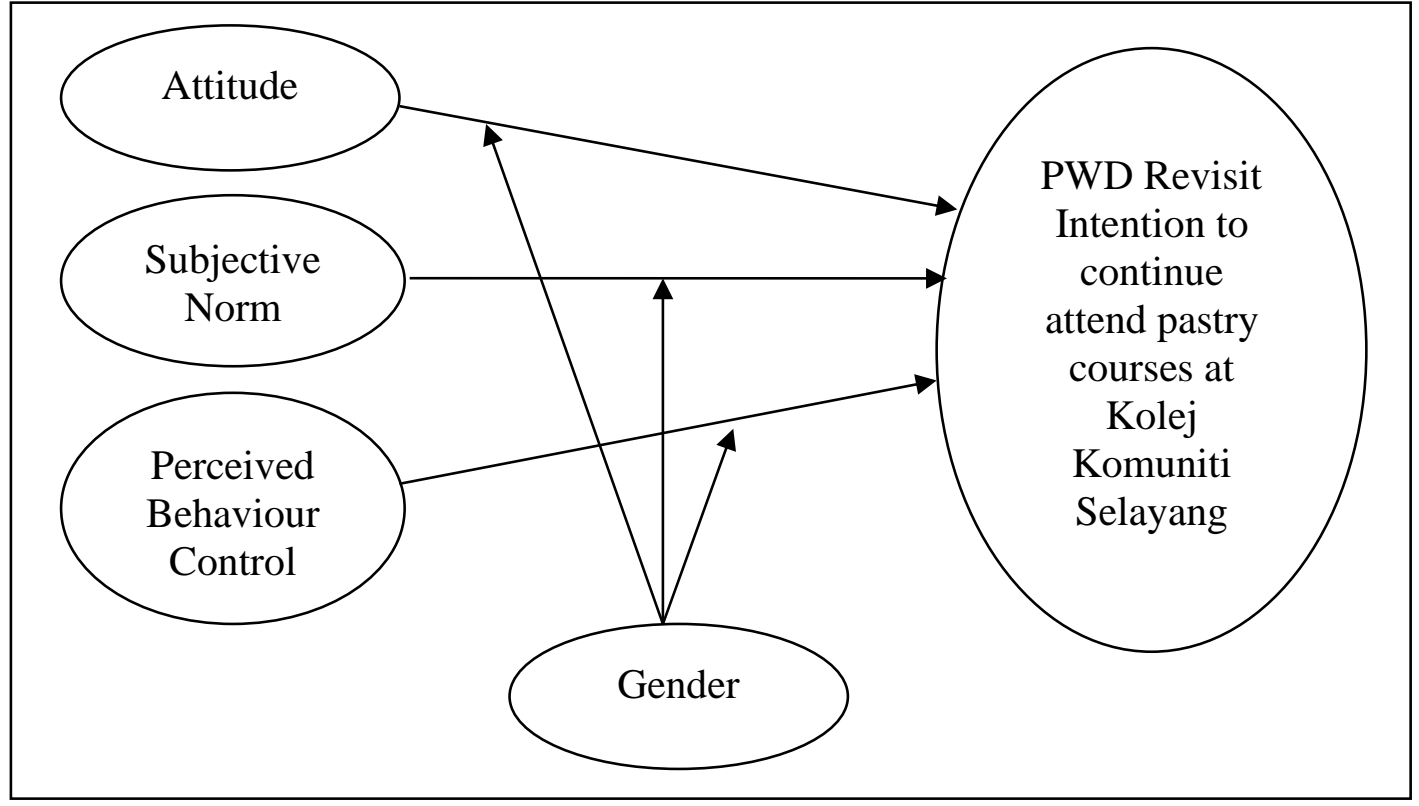

Figure 1: Proposed Conceptual Framework adapt from Theory of Planned Behaviour Source: Ajzen (1991)

\section{Methodology}

This research employed quantitative survey method, and the data were collected from PWD students in Selangor and Kuala Lumpur to investigate the relationships between three considerations in TPB with PWD revisit intention to attend pastry courses at KKSY. The target populations are the PWD students who have attended at least one pastry course at the KKSY. Two academicians from tourism and hospitality programme and one expert from the industry were consulted to test the instrument validity. Following that, a pilot study was carried out, and the data were collected from 36 students to test the reliability of the questionnaire. The analysis of the data in the pilot study showed the value of the Cronbach's alpha was higher than 0.7 .

The items in the questionnaire were adapted from Magdalene et al (2015). The items were measured using 5 points Likert scale ranging from 'strongly disagree' to 'strongly agree'. The three items in revisit intention were: "I intend to take again pastry courses at KKSY", "I would take again pastry courses at KKSY" and "I would actively seek out for take again pastry courses at KKSY". Statistical Package for the Social Sciences (SPSS) was used as a tool of analysis in this study. To measure the reliability, Cronbach's alpha coefficient was used, and the score was 0.912. The data were obtained by the distribution of online questionnaires using google form to PWD students in Selangor and Kuala Lumpur with the guidance from the teachers in each respective school. However, only 146 questionnaires were returned, and all responses were usable. Based on Roscoe (1975), the response rate is sufficient given that the number of respondents is higher than minimum numbers.

\section{Findings}

Statistical Package for the Social Sciences (SPSS) version 26.0 was used to analyse the data for statistical findings. The data were divided into two sections; the descriptive evaluation of demographic profile, followed by the statistical analyses. The data gathered from 12 schools in the Klang Valley area where PWD students were attending. The frequency analysis shows that 59.6 percent of 146 respondents were males, and the rest, 40.4 percent were females. More 
than half of the respondents (60 percent) came from the age group between 13 to 17 years old, while the other 40 percent respondents were between 18 to 22 years old. It is also discovered that 46 respondents (30.1 percent) had attended the short courses at KKSY twice. The other 100 respondents (69.9 percent) had attended the short courses at KKSY three times and more. The internal consistencies of the research instruments were analysed using Cronbach $\alpha$ scores with the reliability scores for all variables between 0.771 and 0.894 .

Table 1: Regression analysis results

\begin{tabular}{lccccccc}
\hline Variable & Coefficient & $\begin{array}{c}\text { Standard } \\
\text { error }\end{array}$ & $t$ & $R^{2}$ & $\begin{array}{c}\text { Adjusted } \\
\text { R Square }\end{array}$ & $\begin{array}{c}\text { F- } \\
\text { statistic }\end{array}$ & Sig. \\
\hline ATTD & 0.784 & 0.056 & 13.940 & 0.574 & 0.571 & 194.330 & $0.000^{* *}$ \\
$\square$ RI & & & & & & & \\
SN $\square$ RI & 0.732 & 0.053 & 13.763 & 0.568 & 0.565 & 189.414 & $0.000^{* *}$ \\
PBC $\square$ RI & 0.824 & 0.054 & 15.190 & 0.616 & 0.613 & 230.740 & $0.000^{* *}$ \\
\hline \multicolumn{8}{c}{ Notes: $\mathrm{N}=146, * *<<0.01$} \\
\end{tabular}

To see the relationship between the independent variables and dependent variable, the three hypotheses were tested using correlation analysis. Based on the result, correlation coefficient between perceived behavioural control and revisit intention to attend pastry courses is significant with the strongest predictor value of 0.824 with 0.01 significance level. The result is followed by attitude $(0.784, p<0.01)$ and subjective norms $(0.732, p<0.01)$. For further and upgraded analysis, regression analysis was applied to determine the impact of internal and external factors that contributed to the study findings. Table 1 presents the regression analysis result; the $R^{2}$ of 0.574 indicates that 57.4 percent of variance in PWD behavioural intention can be predicted by the attitudes variable.

In addition, subjective norm indicates 56.8 percent, and perceived behavioural control brings 61.6 percent to predict the dependent variable. The positive coefficients for all independent variables were found to be statistically significant in suggesting the PWD behavioural intention to attend pastry courses at KKSY. Moreover, the significance F-value shows that all variables are positively significant at 0.01 levels. Hence hypotheses $H 1, H 2$ and $H 3$ are supported, and this study concluded that attitude, subjective norm and perceived behavioural control affect the revisit intention of the PWD to continue attending pastry courses at KKSY in the near future. The moderating effect of gender was conducted, the results show one out of three models considered presented statically significant interaction effects: interaction between the gender and subjective norm scale (beta $0.13, P<0.020$ ); as shown in Table 2. In summary, as shown in Table 3, $H 4 a$ and $H 4 c$ are rejected and $H 4 b$ is supported.

Table 2: Summary of Regression Models Testing Significance of Main Interactions Effects of TPB-Related Scales and Gender

\begin{tabular}{llccc}
\hline Model & & Beta & SE (beta) & $P$ value \\
\hline Model 1 & Attitude towards & 0.588 & 0.175 & 0.001 \\
& $\begin{array}{l}\text { behaviours } \\
\text { Gender }\end{array}$ & -0.486 & 0.491 & 0.324 \\
& Gender x Attitude & 0.131 & 0.112 & 0.246 \\
& towards behaviours & & & \\
Model 2 & Subjective norms & 0.372 & 0.160 & 0.022 \\
Copyright $\odot$ GLOBAL ACADEMIC EXCELLENCE (M) SDN BHD - All rights reserved & &
\end{tabular}


Gender

Gender x Subjective

norms

Model 3

Perceived Behavioural

Control

Gender

Gender x Perceived

Behavioural Control

0.249

0.809

0.026

0.009
DOI: 10.35631/IJEMP.413002

$\begin{array}{ll}0.460 & 0.033 \\ 0.105 & 0.020\end{array}$

0.020

0.166

0.000

0.477

0.957

0.111

0.936

Table 3: Hypotheses Result

\begin{tabular}{cllclc}
\hline Hypotheses & \multicolumn{1}{c}{ Variable } & \multicolumn{1}{c}{ Result } & Hypotheses & \multicolumn{1}{c}{ Variable } & \multicolumn{1}{c}{ Result } \\
\hline$H 1$ & ATTD ->RI & Supported & $H 4 a$ & ATTD, Gender $->$ & Rejected \\
& & & & RI & \\
$H 2$ & SN -> RI & Supported & $H 4 b$ & SN, Gender ->RI & Supported \\
$H 3$ & PBC ->RI & Supported & $H 4 c$ & PBC, Gender -> RI & Rejected \\
\hline
\end{tabular}

\section{Discussion}

This study investigated the relationship between three considerations of TPB with the PWD's revisit intention for attending pastry courses at KKSY with gender as a moderator variable. The data was obtained via self-collection using a google form questionnaire which was given to respondents. The findings indicate that hypothesis $H 1, H 2$ and $H 3$ were supported; there was indeed a significant relationship with the PWD's revisit intention to pastry courses at KKSY. As expected, PBC was found to be the most important variable in predicting the PWD's pastry course revisit intention followed by attitude towards behaviour and the PWD's subjective norms. The PWD community is very special group in that they have a strong internal locus of control, so they know what they want and what they see. As stated by Ajzen (1991), it is about the PWD's belief that they have control in accessing resources and opportunities to perform the behaviour in question. Their mind-set resolve, and of course, their teacher's guidance factors into their ultimate success. This study showed that the PWD still has the intention to attend the pastry course and improved their skills. These findings accord with previous research conducted by Jnr et al. (2020), Joo et al. (2020) and Teo (2019).

PWD's attitude towards the behaviour intention was found to be the second most important predictor in this study. The attitude towards behaviour was a good predictor in TPB and research aligned with Ahmed (2010), Hasan et al. (2020) and Hsu (2013). The PWD's feeling towards the pastry courses positively impacted their mission and future careers. For them, the pastry courses allowed them to manage their skills and learn about pastry products, in order to one day become pastry workers or pastry entrepreneurs. The last predictor was PWD subjective norms. In this study, subjective norm referred to the combination of PWD's perceived social pressure and revisit intention for pastry courses at KKSY. Subjective norm showed a significant positive relationship with the PWD's revisit intention may have been influenced by the teacher's encouragement and the active promotion from KKSY as well. The study results are aligned with IIman et al. (2020), Magdelene et al. (2015) and Yeou (2016), thus, teachers and other relevant parties should keep pushing PWD to become semi-skilled workers before they enter the real workplace.

The moderating effect of gender in this study showed that is invariance for the attitude toward behaviour and perceived behavioural control with the revisit intention, and this result was 
consistent with previous study (Bo Meng \& Heesup Han, 2018; Ilman et al. 2020; Nigg, Lippke \& Maddock, 2009). Therefore, hypothesis $H 4 a$ and $H 4 c$ was rejected. However, there is moderation effect trace on the relationship of subjective norm and behaviour intention. The result showed that relevant opinion from other individuals who are important to the PWD about entrepreneurial training is under considerable to PWD of certain gender. Based on previous research, men have a stronger intention to be entrepreneurial while women have a more difficult environment to think about entrepreneurial-related activities (BarNir, Watson \& Hutchins, 2011; Ilman et al., 2020). This study suggests that teachers/educators would do well to give increased attention to female PWD students and encourage them to join the entrepreneurial based activities.

\section{Conclusion, Limitation and future research}

In keeping with the aim for developing a high-quality education environment, the right to education should be guaranteed on the basis of equality of opportunity irrespective of academic ability. In other words, both PWD and conventional students should enjoy equal opportunity without discrimination. Thus, the main objective of this study was to examine the three predictors of TPB with PWD revisit intention for pastry courses at KKSY and to also see the moderation effect of gender in the relationship. The findings of this study will engender relevant knowledge for parents, teachers and KKSY educators about factors that influence PWD students to re-attend pastry courses at KKSY. Moreover, PWD have a choice to develop their passions and careers and align themselves with the training courses offered by the technical and vocational institutions in Malaysia. This shows the government's desire to develop an entrepreneurial intention since they are at the higher education level which is expected to help drive the economy in the future.

The results have shown that attitude towards behaviour, subjective norm, and perceived behavioural control significantly contribute to the PWD revisit intention to continue attending pastry courses at KKSY. The findings from this study, however, cannot be generalized since the questionnaire was disseminated only to the specific area in the Klang Valley area. It is suggested to extend the research to the larger sample of respondents from all PWD in 14 states in Malaysia. Furthermore, future researchers are suggested to extend the research on courses provided for different skills involving PWD in technical and vocational institutions. The findings from this study emphasize the importance of entrepreneurial education for PWD in order to support and create newer young PWD entrepreneurs.

\section{References}

Abdul Khalek, A., \& Syed Ismail, S. H. (2015). Why Are We Eating Halal - Using the Theory of Planned Behavior in Predicting Halal Food Consumption among Generation Y in Malaysia. International Journal of Social Science and Humanity, 5(7), 608-612. http://doi.org/10.7763/IJSSH.2015.V5.526

Ahmad, S., Jalil, W. N. W. A., \& Rahman, R. A. (2020). SKM-KVS Pre-Pilot Program for Pastry Making: Pastry Production Skills by Special Needs Pupils (Mbk) in TVET Curriculum Collaboration with Sungai Petani Community College. In International Conference on Special Education In South East Asia Region 10th Series 2020 (pp. 4257). Redwhite Press.

Ahmed, H.M.S. (2010), "Hybrid E-Learning acceptance model: learner perceptions", Decision Sciences Journal of Innovative Education, Vol. 8 No. 2, pp. 313-346. 
Ashraf, M. S., Hou, F., Kim, W. G., Ahmad, W., \& Ashraf, R. U. (2020). Modeling tourists' visiting intentions toward ecofriendly destinations: Implications for sustainable tourism operators. Business Strategy and the Environment, 29(1), 54-71.

Ajzen I. (2020). The theory of planned behavior: Frequently asked questions. Hum Behav \& Emerg Tech. 2020(2), 314-324. https://doi.org/10.1002/hbe2.195

Ajzen, I. (1991), "The theory of planned behaviour", Organizational Behaviour and Human Decision Processes, Vol. 50 No. 2, pp. 179-211.

Anwar, I., Saleem, I., Islam, K. B., Thoudam, P., \& Khan, R. (2020). Entrepreneurial intention among female university students: examining the moderating role of entrepreneurial education. Journal for International Business and Entrepreneurship Development, 12(4), 217-234.

Baker, D. A., \& Crompton, J. L. (2000). Quality, satisfaction and behavioral intentions. Annals of Tourism Research, 27(3), 785-804. doi:10.1016/S0160-7383(99)00108-5

BarNir, A., Watson, W. E., \& Hutchins, H. M. (2011). Mediation and Moderated Mediation in the Relationship Among Role Models, Self-Efficacy, Entrepreneurial Career Intention, and Gender. Journal of Applied Social Psychology. https://doi.org/10.1111/j.15591816.2010.00713.x

Bokolo, A. J. (2020). Predictors of Blended Learning Deployment in Institutions of Higher Learning: Theory of Planned Behavior Perspective. The International Journal ofInformation and Learning Technology, DOI 10.1108/IJILT-02-2020-0013

Bo Meng \& Heesup Han. (2018). Investigating individuals' decision formation in workingholiday tourism: the role of sensation-seeking and gender, Journal of Travel \& TourismMarketing, DOI: 10.1080/10548408.2017.1422455

Dakduk, S., Santalla-Banderali, Z. and van der Woude, D. (2018), "Acceptance of blended learning in executive education", SAGE Open, Vol. 8 No. 3, 2158244018800647.

Dwivedi, M. (2018). Skill Development in Learners with Disabilities in Higher Education. Multidisciplinary Higher Education, Research, Dynamics \& Concepts: Opportunities \& Challenges For Sustainable Development (ISBN 978-93-87662-12-4), 1(1), 150-152.

ESCAP, U. (2012). Incheon strategy to "make the right real" for persons with disabilities in Asia and the Pacific. United Nations Publication, Bangkok: Thailand.

Engr Amaechi, O. J., Orlu, I., Obed, O. O., \& Thomas, C. G. (2017). World Journal of Engineering Research and Technology WJERT. World Journal of Engineering, 3(2), 17-30.

Fishbein, M., \& Ajzen, I. (1975). Belief, attitude, intention, and behavior: An introduction totheory and research. Reading, MA: Addison-Wesley.

Halimatussadiah, A., Agriva, M., \& Nuryakin, C. (2015). Persons with Disabilities (PWD) and Labor Force in Indonesia: A Preliminary Study Development, 17(18), 19.

Handicapped and jobless (2020, February 12). New Straits Times. Retrieved from https://www.nst.com.my/education/2020/02/564906/handicapped-and-jobless

Hasan, M. K., Abdullah, S. K., Islam, F., \& Neela, N. M. (2020). An Integrated Model for Examining Tourists' Revisit Intention to Beach Tourism Destinations. Journal of Quality Assurance in Hospitality \& Tourism, 1-22.

Hsu, M.C. (2013), "The management of sports tourism: a causal modelling test of the theory of planned behaviour", International Journal of Management, Vol. 30 No. 2, pp. 474496.

Ilman, A. H., Ananda, N. A., \& Pohan, A. S. (2020). Entrepreneurial Education and University Environment toward Students Entrepreneurial Intention. International Journal of Innovative Science and Research Technology 5 (1), 1271-1278. 
Jing Wang, Shanyong Wang, Yu Wang, Jun Li, Dingtao Zhao, (2018) "Extending the theoryof planned behavior to understand consumers' intentions to visit green hotels in the Chinese context", International Journal of Contemporary Hospitality Management, https://doi.org/10.1108/IJCHM-04-2017-0223

Jnr, B. A., Kamaludin, A., Romli, A., Raffei, A. F. M., Phon, D. N. A. E., Abdullah, A., \& Baba, S. (2020). Predictors of blended learning deployment in institutions of higher learning: theory of planned behavior perspective. The International Journal of Information and Learning Technology.

Joo, Y., Seok, H., \& Nam, Y. (2020). The Moderating Effect of Social Media Use on Sustainable Rural Tourism: A Theory of Planned Behavior Model. Sustainability, 12(10), 4095.

Lam, T. and Hsu, C.H.C. (2006), "Predicting behavioural intention of choosing a travel destination", Tourism Management, Vol. 27 No. 4, pp. 589-599.

Lee, S., Jeong, E., \& Qu, K. (2020). Exploring Theme Park Visitors' Experience on Satisfaction and Revisit Intention: A Utilization of Experience Economy Model. Journal of Quality Assurance in Hospitality \& Tourism, 21(4), 474-497.

Manosuthi, N., Lee, J. S., \& Han, H. (2020). Predicting the revisit intention of volunteer tourists using the merged model between the theory of planned behavior and norm activation model. Journal of Travel \& Tourism Marketing, 37(4), 510-532.

McDonnall, M. C., \& Lund, E. M. (2020). Employers' Intent to Hire People Who Are Blind or Visually Impaired: A Test of the Theory of Planned Behavior. Rehabilitation Counseling Bulletin, 63(4), 206-215.

Nasri, M. S. B., Hamzah, R., \& Udin, A. (2010). Falsafah Pendidikan Kebangsaan Memperkasakan Peranan Pendidikan Teknik Vokasional Dan Pendidikan Khas.

Nigg, C. R., Lippke, S., \& Maddock, J. E. (2009). Factorial invariance of the theory of planned behavior applied to physical activity across gender, age, and ethnic groups. Psychology of Sport \& Exercise, 10(2), 219-225. doi:10.1016/j.psychsport.2008.09.005

Oliver, R. L. (1997). Satisfaction: A behavioral perspective on the consumer. New York, NY:McGraw-Hill.

Oliver, R. L., \& Swan, J. E. (1989). Equity and disconfirmation perceptions as influences onmerchant and product satisfaction. Journal of Consumer Research, 16(3), 372383.doi:10.1086/jcr.1989.16.issue-3

Pendidikan Untuk Semua Elak Tercicir (2019, December 21) BH Online.

Retrieved from https://www.bharian.com.my/kolumnis/2019/12/640509/pendidikanuntuk-semua elak-tercicir

Prasetya, A., \& Mawardi, M. K. (2019). Opportunities and Challenges of Entrepreneurship Approach for People with Disability Empowerment in a Developing Country. In Annual International Conference of Business and Public Administration (AICoBPA 2018). Atlantis Press.

Raab C., Baloglu S. \& Chen Y. (2017): Restaurant Managers' Adoption of Sustainable Practices: An Application of Institutional Theory and Theory of Planned Behavior, Journal of Foodservice Business Research, DOI: 10.1080/15378020.2017.1364591

Rosli, H. F., Mahmud, W. A. W., \& Mahbob, M. H. (2016). Peranan media sebagai alat kesedaran sosial dalam kalangan orang kurang upaya di Malaysia. Jurnal Komunikasi: Malaysian Journal of Communication, 32(2).

Quinn, G. (2009). The United Nations Convention on the Rights of Persons with Disabilities: Toward a new international politics of disability. Tex. J. on CL \& CR, 15, 33. 
Shodipe, T. O., \& Ohanu, I. B. (2020). Antecedents of entrepreneurial intentions of electrical installation and maintenance work students' in technical colleges. Asia Pacific Journal of Innovation and Entrepreneurship. 14(2), 127-137

Soorani, F., \& Ahmadvand, M. (2019). Determinants of consumers' food management behavior: Applying and extending the theory of planned behavior. Waste Management, 98, 151-159.

Strobl, A., Kronenberg, C., \& Peters, M. (2012). Entrepreneurial attitudes and intentions: assessing gender specific differences. International Journal of Entrepreneurship and Small Business. https://doi.org/10.1504/IJESB.2012.046475

Suid, I. S., Nor, N. A. B. M., \& Omar, H. B. (2017). The Application of TPB on Inbound Muslim Travellers' Revisit Intention to Malaysia. Journal on Technical and Vocational Education, 2(1), 6-17.

Sun, H., Lo, C. T., Liang, B., \& Wong, Y. L. B. (2017). The impact of entrepreneurial education on entrepreneurial intention of engineering students in Hong Kong. Management Decision.

Tahir, L., \& Mustafa, N. Q. (2008). Faktor-faktor yang Mempengaruhi Keberkesanan Pendidikan Khas Teknik dan Vokasional untuk Golongan Orang Kurang Upaya di Tiga Buah Politeknik. Johor: Universiti Teknologi Malaysia (UTM).

Teo, T. (2019), "Students and teachers' intention to use technology: assessing their measurement equivalence and structural invariance", Journal of Educational Computing Research, Vol. 57 No. 1, pp. 201-225.

Wang, L., \& Wong, P. P. W. (2020). Marketing of environmentally friendly hotels in China through religious segmentation: a theory of planned behaviour approach. Tourism Review.

Warshaw, P. R., \& Davis, F. D. (1985). Disentangling behavioural intention and behavioural expectation. Journal of Experimental Social Psychology, 21(3), 213-228.

Yarimoglu E \& Gunay T. (2019). The extended theory of planned behavior in Turkish Customers' intentions to visit green hotels. Bus Strat Env. 2019;1-12. https://doi.org/10.1002/bse.2419

Yeou, M. (2016), “An investigation of students' acceptance of moodle in a blended learning setting using technology acceptance model", Journal of Educational Technology Systems, Vol. 44 No. 3, pp. 300-318. 